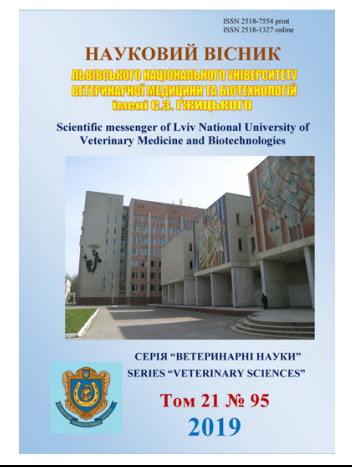

\author{
Науковий вісник Дьвівського націонадьного університету \\ ветеринарної медицини та біотехнологій імені С.3. Гжицького. \\ Серія: Ветеринарні науки \\ Scientific Messenger of Lviv National University \\ of Veterinary Medicine and Biotechnologies. \\ Series: Veterinary sciences
}

UDC 615.33.636.09

\title{
Antimicrobial activity of danofloxacin regarding to bacteria, pathogens of respiratory infections in pigs
}

\author{
T.I. Stetsko, I.Ia. Kotsiumbas, Ya.M. Liubenko, V.N. Padovskyi, H.P. Uhryn
}

State Scientific-Research Control Institute of Veterinary Medicinal Products and Feed Additives, Lviv, Ukraine

Article info

Received 03.09.2019

Received in revised form 02.10 .2019

Accepted 03.10.2019

State Scientific-Research Control Institute of Veterinary Medicinal Products and Feed Additives 11, Donetska str., Lviv, 79019, Ukraine.

Tel.: +38-067-252-98-29 E-mail: stetskot@ukr.net
Stetsko, T.I., Kotsiumbas, I.Ia., Liubenko, Ya.M., Padovskyi, V.N., \& Uhryn, H.P. (2019). Antimicrobial activity of danofloxacin regarding to bacteria, pathogens of respiratory infections in pigs. Scientific Messenger of Lviv National University of Veterinary Medicine and Biotechnologies. Series: Veterinary sciences, 21(95), 22-26. doi: 10.32718/nvlvet9504

The objective of the research was to study the antimicrobial activity of danofloxacin, the thirdgeneration fluoroquinolone antibiotic, against bacteria, pathogens of acute respiratory infection in pigs. Samples of nasal excretions were selected from clinically sick weaned piglets with acute respiratory infection for microbiological investigation. The sensitivity test, carried out by the disc-diffusion method, showed a high level of the microflora sensitivity of the inflammatory exudate to danofloxacin. Bacteria Streptococcus suis and Bordetella bronchiseptica have been isolated and identified from biomaterial by generally accepted microbiological methods. The degree of antimicrobial activity of danofloxacin against isolated strains of microorganisms was established by determination the minimum inhibitory concentration (MIC) of danofloxacin for isolated bacteria by consecutive dilutions in a liquid nutrient medium. The MIC average of danofloxacin for Streptococcus suis isolates $(n=20)$ was $0.33 \pm$ $0.082 \mu \mathrm{g} / \mathrm{ml}$ and for Bordetella bronchiseptica isolates $(n=8)-0.21 \pm 0.044 \mu \mathrm{g} / \mathrm{ml}$. The obtained results showed a high level of bacteriostatic activity of danofloxacin regarding bacterial isolates, pathogens of acute respiratory infection in pigs. Danofloxacin, like other fluoroquinolones, is a critical antimicrobial substance for veterinary medicine. Therefore, chemotherapeutic agents based on this antibiotic can serve as a drug of choice for empirical treatment of pigs with acute respiratory infections of bacterial etiology. To right choose an effective agent for etiotropic therapy and minimize the selection of resistant strains of microorganisms, the antimicrobial susceptibility of isolated bacteria should be pre-established.

Key words: fluoroquinolones, danofloxacin, pigs, respiratory infections, bacteria, Streptococcus suis, Bordetella bronchiseptica, antimicrobial sensitivity of microorganism, minimal inhibitory concentration.

\section{Антимікробна активність данофлоксацину щодо бактерій, збудників гострої респіраторної інфекції у свиней}

Т.І. Стецько, І.Я. Коцюмбас, Я.М. Любенко, В.Н. Падовський, Г.П. Угрин

Державний науково-дослідний контрольний інститут ветеринарних препаратів та кормових добавок, м. Львів, Україна

Метою дослідження було вивчення антимікробної активності фторхінолонового антибіотика третього покоління данофлоксацину щодо бактерій, збудників гострої респіраторної інфекції у свиней. Від клінічно хворих на гостру респіраторну інфекцію відлучених поросят для мікробіологічних досліджень відбирали зразки носових виділень. Тест на чутливість, проведений дискодифузійним методом, показав високий рівень чутливості мікрофлори запального ексудату до данофлоксацину. Загальноприйнятими мікробіологічними методами з біоматеріалу були виділені та ідентифіковані бактерії Streptococcus suis i Bordetella bronchiseptica. Ступінь антимікробної активності данофлоксацину щзодо виділених штамів мікроорганізмів встановлювали иляхом визначення мінімальної інгібуючої концентрації (МІК) данофлоксацину для бактерій-ізолятів методом послідовних розведень у рідкому поживному середовищі. Середнє значення МIK данофлоксацину для ізолятів Streptococcus suis (n = 20) становило 
0,33 = 0,082 мкг/мл, а для ізолятів Bordetella bronchiseptica $(n=8)-0,21 \pm 0,044$ мкг/мл. Отримані результати показали високий рівень бактеріостатичної активності данофлоксачину щзодо бактерій-ізолятів, збудників гострої респіраторної інфекції у свиней. Данофлоксацин, як й інші фторхінолони, є критично важливою антимікробною речовиною для ветеринарної медицини. Відтак хіміотерапевтичні засоби на основі иього антибіотика можуть служити препаратами вибору за емпіричного лікування свиней при гострих респіраторних інфекціях бактеріальної етіології. Для правильного вибору ефективного засобу етіотропної терапї та мінімізації селекції резистентних итамів мікроорганізмів слід попередньо встановити антимікробну чутливість бактерій-ізолятів.

Ключові слова: фторхінолони, данофлоксацин, свині, ресnipaторні інфекиії, бактерї, Streptococcus suis, Bordetella bronchiseptica, антимікробна чутливість мікроорганізмів, мінімальна інгібуюча концентрація.

\section{Вступ}

Респіраторні захворювання свиней широко поширені практично у всіх країнах світу з розвиненим свинарством, чим завдають фермерам великих економічних збитків. Вважають, що інфекції дихальних шляхів $\epsilon$ однією з основних причин захворюваності та смертності у поросят після відлучення (Straw et al., 1983; Losinger et al., 1998). У різних господарствах захворюваність поросят на респіраторні хвороби зазвичай становить 30-70\%, а летальність може досягати 40\% (Orljankin et al., 2010). У США 39,1\% усіх випадків загибелі пост-відлучених поросят пов'язане з захворюваннями органів дихання (Losinger et al., 1998). Респіраторні інфекції викликають зниження темпів росту молодняку свиней (Christensen, 1995) та зростання конверсії кормів (Straw et al., 1989).

Збудниками респіраторних хвороб свиней є віруси і бактерії, причому часто їх асоціації. Так, наприклад, вірус репродуктивно-респіраторного синдрому свиней (РРСС), окрім репродуктивної системи, вражає органи дихання поросят після відлучення. Персистуючи в їхньому організмі та розмножуючись у клітинах імунної системи (лімфоцитах і макрофагах), вірус руйнує ïx, призводить до імунодефіцитних станів. У таких тварин створюються умови для залучення в інфекційний процес бактеріальних респіраторних патогенів, таких як: Mycoplasma hyopneumoniae, Actinobacillus pleuropneumoniae, Haemophilus parasuis, Pasteurella multocida, Salmonella choleraesuis, Streptococcus suis, Bordetella bronchiseptica та інші (Palunina, 2004; Orljankin et al., 2005; Bochev, 2007; Hansen et al., 2010). Багато 3 цих мікроорганізмів можуть діяти як опортуністичні мікроорганізми на вже ослаблену імунну систему поросят (Opriessnig et al., 2011).

Усі бактеріальні респіраторні патогени, залежно від здатності викликати захворювання, поділяють також на три групи (Stevenson, 1998; Thacker, 2001; Done, 2002). До першої групи належать основні (первинні) бактеріальні патогени, які потрапляють в організм свиней респіраторним шляхом, викликаючи розвиток пневмонії. Вони мають фактори вірулентності, котрі долають природний захист в легенях тварини. До цієї групи відносять Mycoplasma hyopneumoniae, Actinobacillus pleuropneumoniae, Bordetella bronchiseptica. Друга група включає другорядні (вторинні) патогени, які потрапляючи через верхні дихальні шляхи поросят, не викликають пневмонії. Для iii розвитку потрібне пошкодження легенів, обумовлене пневмотропними вірусами або мікоплазмами. До цієї групи належать Pasteurella multocida,
Haemophilus parasuis, Streptococcus suis, Mycoplasma hyorhinis. Третя група включає бактеріальні патогени, що переносяться кров'ю при розвитку септицемії. До цієї групи належать Salmonella choleraesuis, Actinobacillus suis, Actinomyces pyogenes (Arcanobacterium pyogenes).

Для лікування респіраторних захворювань бактеріальної етіології у свиней широко використовуються антибактеріальні препарати. Вибір ефективного хіміотерапевтичного засобу часто ускладнений наявністю антибіотикорезистентних штамів збудника чи збудників інфекції, причому опірність мікроорганізмів зазвичай носить полірезистентний характер. Тому для досягнення терапевтичного ефекту важливим є правильний вибір антибактеріального засобу, який би містив активнодіючу речовину, до дії якої чутливий мікроорганізм - збудник захворювання.

Фторхінолони належать до критично важливих антимікробних препаратів для ветеринарної медицини (Stetsko et al., 2018) завдяки широкому спектру бактерицидної дії, безпечності, а також фармакокінетичним i фізико-хімічним властивостям, високому ступеню біодоступності та проникнення в тканини і клітини макроорганізму (Brown, 1996; Papich \& Riviere, 2001). Фторхінолони, завдяки відсутності аналогів у природному середовищі, забезпечують відносно високу активність щодо полірезистентних штамів мікроорганізмів. Розвиток резистентності мікроорганізмів до дії фторхінолонів проходить значно повільніше, ніж до антибіотиків інших груп (Brown, 1996; MartinezMartinez et al., 1998; Stetsko, 2005). Для антибіотиків цієї групи не характерна перехресна резистентність 3 іншими класами антибіотиків (Stetsko, 2005).

Мета дослідження - вивчити антимікробну активність фторхінолонового антибіотика третього покоління данофлоксацину щодо бактерій, збудників гострої респіраторної інфекції у свиней. Завдання дослідження - виділити та ідентифікувати мікроорганізми, збудники гострої респіраторної інфекції у молодняку свиней та встановити ступінь чутливості бактерійізолятів до данофлоксацину.

\section{Матеріал і методи досліджень}

Для досліджень використовували новий антибактеріальний препарат Данофлокс 2,5\% (розчин для ін'єкцій) виробництва ПАТ “Галичфарм", діючою речовиною якого $є$ фторхінолоновий антибіотик третього покоління данофлоксацин. Суб'єктами дослідження були 20 поросят породи велика біла різної 
статі 2-місячного віку, з клінічними ознаками гострої респіраторної інфекції (пневмонії).

Від хворих поросят за допомогою стерильних ватних тампонів відбирали зразки носових виділень. Чутливість до данофлоксацину мікрофлори носового ексудату визначали диско-дифузійним методом (Metodychni vkazivky po vyznachenniu chutlyvosti mikroorhanizmiv..., 2010). Для цього використовували стандартні паперові диски, які просочували розчином данофлоксацину таким чином, щоб кожний диск містив в собі 5 мкг цього антибіотика. Інтерпретацію результатів визначення чутливості мікрофлори носового ексудату до данофлоксацину здійснювали за такими критеріями: діаметр зони затримки росту навколо диску з данофлоксацином $\geq 22$ мм - мікрофлора чутлива; 18-21 мм - мікрофлора помірно чутлива; $\leq 17$ мм - мікрофлора резистентна (National Committee for Clinical Laboratory Standards, 2004). Для виділення мікроорганізмів проводили первинний посів біоматеріалу на звичайний агар (МПА). Отримані ізольовані колонії пересівали в пробірки з МПБ і МПА для отримання чистої культури. Виділення та ідентифікацію мікроорганізмів проводили за загальноприйнятими мікробіологічними методиками
(Golovko et al., 2007; Kravtsiv et al., 2008). Рівень бактеріостатичної активності препарату Данофлокс 2,5\% встановлювали шляхом визначення мінімальної інгібуючої концентрації (МІК) данофлоксацину для бактерій-ізолятів методом серійних розведень у рідкому поживному середовищі (Metodychni vkazivky..., 2007). Для цього готували послідовні розведення препарату Данофлокс 2,5\% таким чином, щоб отримати розчини 3 концентрацією данофлоксацину 50,0; 25,$0 ; \quad 12,5 ; \quad 6,25 ; \quad 3,13 ; \quad 1,6 ; 0,8 ; 0,4 ; 0,2 ; 0,1$; 0,05 мкг $/ \mathrm{cm}^{3}$. Інтерпретацію отриманих результатів МІК данофлоксацину для виділених штамів мікроорганізмів проводили таким чином: штам мікроорганізму вважався чутливим до данофлоксацину, якщо величина МІК була $\leq 0,25$ мкг $/ \mathrm{cm}^{3}$, помірно чутливим -

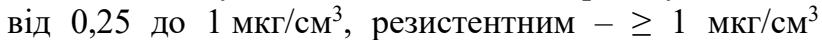
(National Committee for Clinical Laboratory Standards, 2004).

\section{Результати та їх обговорення}

Результати тесту на чутливість до данофлоксацину мікрофлори носових виділень хворих на гостре респіраторне захворювання поросят показані рис. 1 .

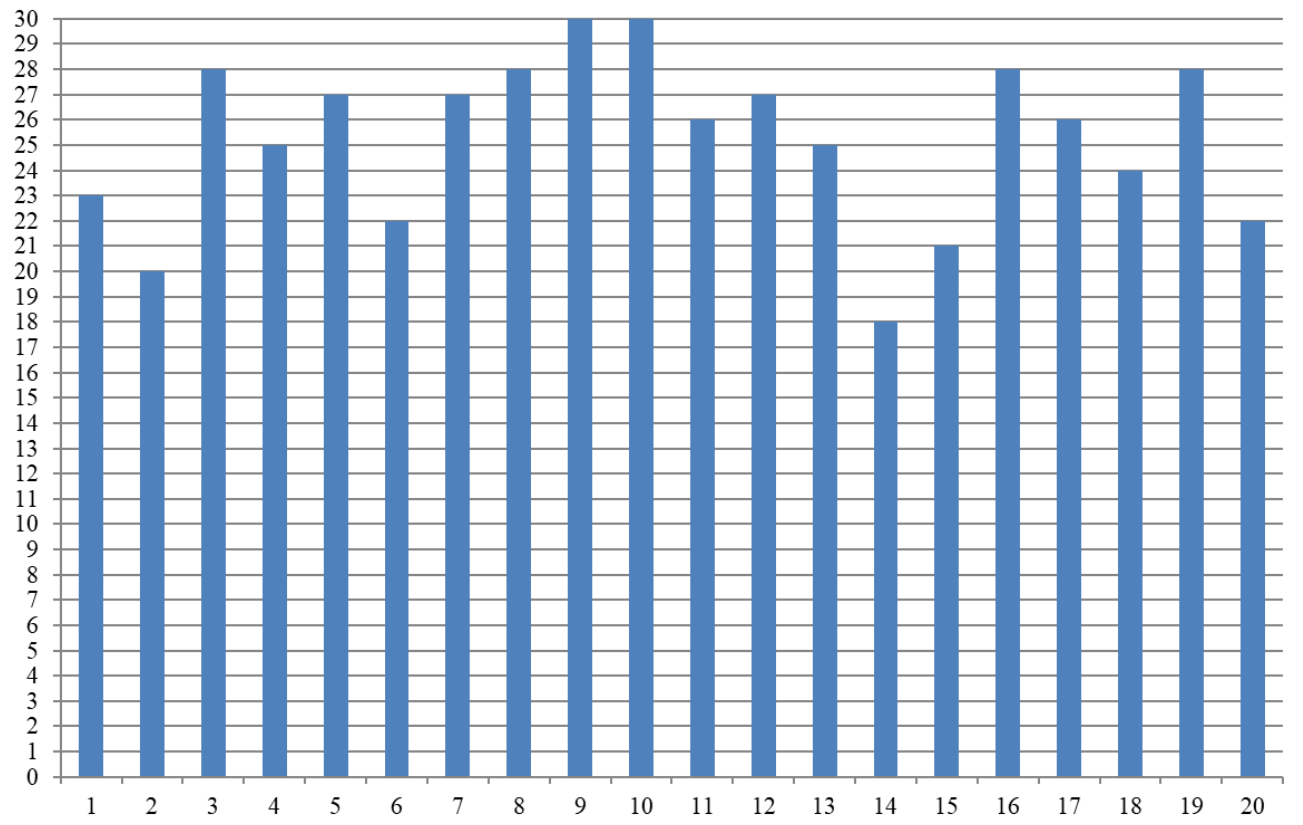

Рис. 1. Діаметр зони затримки росту мікрофлори навколо диску з данофлоксацином, мм $(\mathrm{n}=20)$

Згідно з отриманими результатами тесту на чутливість, мікрофлора 17 зразків носових виділень поросят проявила високу чутливість до данофлоксацину (85\%), а 3 зразки (15\%) - помірну чутливість. Середнє значення діаметру зони затримки росту мікроорганізмів навколо диску 3 данофлоксацином становило $25,25 \pm 0,75$ мм.

3 усіх 20 зразків носового ексудату були виділені й ідентифіковані стрептококи. На МПА вони давали ріст дрібних круглих, з рівними краями колоній, у м'ясо-пептонному бульйоні (МПБ) - легке помутніння, слабкий пристінний ріст та невеликий осад, на кров'яному агарі - зони гемолізу. Мікроскопія мазків виявила типові грампозитивні овальні або кулеподібні клітини 1 мкм в діаметрі, що розташовувалися попарно або ланцюжками різної довжини. Такі морфологічні та культуральні властивості характерні для стрептококу Streptococcus suis. Важають, що Streptococcus suis - на першому місці серед умовно патогенних збудників респіраторних інфекцій у свиней (Huang et al., 2005; Gottschalk et al., 2010; Fittipaldi et al., 2012). Стрептококова пневмонія найбільш поширена серед молодняку свиней, особливо після відлучення, і все частіше реєструється в складі комплек- 
сного респіраторного захворювання (Huang et al., 2005; Gottschalk et al., 2010; Fittipaldi et al., 2012). При цьому стрептокок досить часто пов'язаний з іншими мікроорганізмами, такими як Mycoplasma spp., Pasteurella multocida, Actinobacillus pleuropneumoniae або вірус свинячого грипу (Orljankin et al., 2010; Hansen et al., 2010).

Доведено, що Bordetella bronchiseptica може збільшити вірулентність Str. suis і ускладнити перебіг хвороби (Zhao et al., 2011). У нашому випадку, мікробіологічним дослідженням було встановлено, що у деяких поросят стрептококова інфекція супроводжувалася наявністю іншої умовно-патогенної бактерії Bordetella bronchiseptica (8 ізолятів). На МПА свіжо виділені культури утворювали колонії бірюзового кольору 3 темно-синім центром розміром від 2 до 4 мм. B. bronchiseptica на кров'яному агарі формувала через 24 години дуже дрібні, опуклі, з гладкою блискучою поверхнею і рівними краями колонії з зоною $\beta$ гемолізу. На агарі Мак-Конкі бордетели давали ріст дрібних колоній 3 рожевою периферією і світлим центром. У рідкому поживному середовищі (сироватковий МПБ) $B$. bronchiseptica росла 3 рівномірним помутнінням середовища, в подальшому утворювався осад і пристінкове кільце, і середовище ставало прозорим. При мікроскопії мазків, фарбованих за Грамом, виявляли дрібні грамнегативні кокобацили, рівномірно розташовані в мазку поодиноко, парами або короткими ланцюжками.

Значення МІК данофлоксацину для ізолятів Streptococcus suis показані на рис. 2, а для ізолятів Bordetella bronchiseptica - на рис. 3. За рівнем бактеріостатичної активності 13 ізолятів Streptococcus suis виявилися чутливими до данофлоксацину (65\%), 6 помірно чутливими (30\%), лише один штам цього мікроорганізму - резистентним (5\%). Щодо Bordetella bronchiseptica, 6 штамів цієї бактерії були чутливими до данофлоксацину і 2 штами - помірно чутливими.

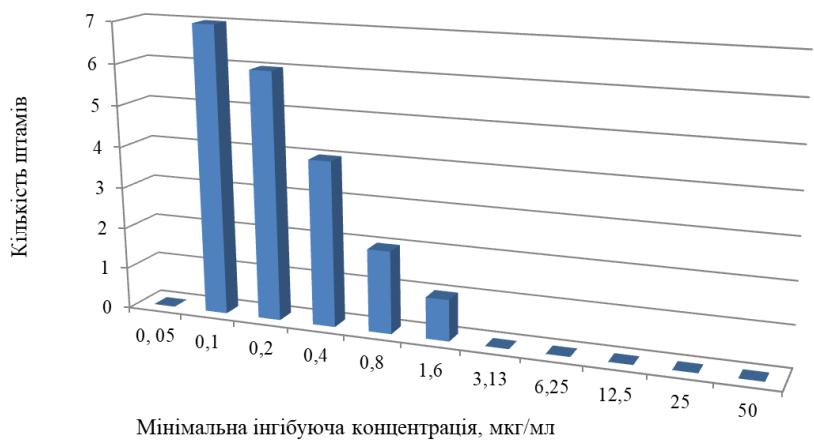

Рис. 2. МІК данофлоксацину для штамів Streptococcus suis, виділених від хворих на респіраторне захворювання поросят $(\mathrm{n}=20)$

Середнє значення МІК данофлоксацину для ізолятів Streptococcus suis становило 0,33 $\pm 0,082$ мкг/мл, а для ізолятів Bordetella bronchiseptica - 0,21 \pm 0,044 мкг/мл. Отримані результати показали високий рівень чутливості бактерій-ізолятів, збудників гострої респіраторної інфекції у свиней, до данофлоксацину.

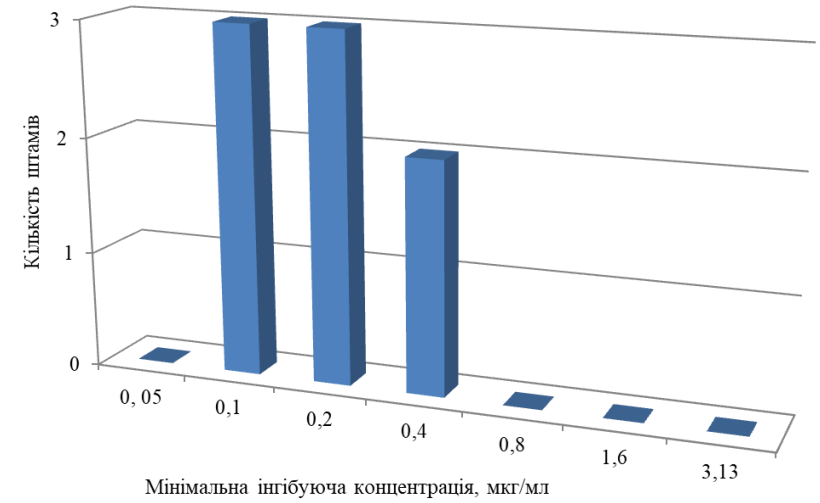

Рис. 3. МІК данофлоксацину для штамів Bordetella bronchiseptica, виділених від хворих на респіраторне захворювання поросят $(\mathrm{n}=8)$

\section{Висновки}

Бактерії є одними з основних причин виникнення респіраторних захворювань незаразного характеру у свиней. Нині антибіотики залишаються основою хіміотерапії респіраторної інфекції бактеріальної етіології у свиней. Ефективність антибактеріальної терапії респіраторних захворювань залежить від чутливості мікроорганізмів, збудників інфекції, до антимікробного засобу. Антибіотики фторхінолонового класу залишаються одними з ефективних та безпечних засобів етіотропної терапії з широким спектром бактерицидної дії. Бактерії-ізоляти, збудники захворювань органів дихання у свиней, зберігають високий рівень чутливості до дії данофлоксацину, фторхінолонового антибіотика третього покоління. Це робить препарати на основі цього фторхінолону антимікробним засобом першочергового вибору при лікуванні бактеріальних респіраторних інфекцій у свиней, особливо при емпіричному підході до терапії.

Перспективи подальших досліджень. Науковопрактичне значення матимуть дослідження, пов'язані 3 вивченням терапевтичної ефективності та безпечності хіміотерапевтичного препарату на основі данофлоксацину при лікуванні респіраторної інфекції бактеріальної етіології у свиней. Актуальним є також дослідження чутливості до данофлоксацину бактерій, збудників інших системних захворювань у свиней.

\section{References}

Straw, B.E., Neubauer, G.D., \& Leman, A.D. (1983). Factors affecting mortality in finishing pigs. Journal of the American Veterinary Medical Association, 183(4), 452-455. https://www.ncbi.nlm.nih.gov/pubmed/ 6618972 .

Losinger, W.C., Bush, E.J., Smith, M.A., \& Corso, B.A. (1998). Mortality attributed to respiratory problems among finisher pigs in the United States. Preventive Veterinary Medicine, 37(1-4), 21-31. https://www.ncbi.nlm.nih.gov/pubmed/9879577. 
Orljankin, B.G., Mishin, A.M., \& Aliper, T.I. (2010). Infekcionnye respiratornye bolezni svinej: jetiologija, diagnostika i profilaktika. Veterinarija Kubani. Krasnodar, 3, 5-7 (in Russian).

Christensen, N.H. (1995). Evaluation of the effects of enzootic pneumonia in pigs on weight gain and days to slaughter under New Zealand conditions. New Zealand Veterinary Journal 43(4),146-148. doi: 10.1080/00480169.1995.35875.

Straw, B.E., Tuovinen, V.K., \& Bigras-Poulin, M. (1989). Estimation of the cost of pneumonia in swine herds. Journal of the American Veterinary Medical Association, 195(12), 1702-1706. https://www.ncbi. nlm.nih.gov/pubmed/2689415.

Bochev, I. (2007). Porcine respiratory disease complex (PRDC): a review. Etiology, epidemiology, clinical forms and pathoanatomical features. Bulgarian Journal of Veterinary Medicine, 10(3), 131-146. https://pdfs.semanticscholar.org/8245/dd62548092df6 6c6612cd7a4a39a440972ff.pdf.

Orljankin, B.G., Aliper, T.I., \& Nepoklonov, E.A. (2005). Infekcionnye respiratornye bolezni svinej. Veterinarija, 11, 3-6 (in Russian).

Palunina, V.V. (2004). Jeksperimental'noe vosproizvedenie bronhopnevmonii u porosjat. Veterinarija, 5, 22-25 (in Russian).

Hansen, M.S., Pors, S.E., Jensen, H.E. et al. (2010). An Investigation of the Pathology and Pathogens Associated with Porcine Respiratory Disease Complex in Denmark. J Comp Pathol., 143(2-3), 120-231. doi: 10.1016/j.jcpa.2010.01.012.

Opriessnig, T., Giménez-Lirola, L.G. \& Halbur, P.G. (2011). Polymicrobial Respiratory Disease in Pigs. Animal Health Peseach Reviews, 12(2), 133-148. doi: $10.1017 / \mathrm{S} 1466252311000120$.

Done, S.H. (2002). Porcine respiratory disease complex (PRDC). The Pig Journal, 50, 174-196.

Stevenson, G.W. (1998). Bacterial pneumonia in swine. Proc. 15th IPVS Congress, 11-20.

Thacker, E.L. (2001). Immunology of the porcine respiratory disease complex. Vet. Clin. North America: Food Anim. Pract., 17, 551-565. https://www.ncbi.nlm.nih.gov/pubmed/11692508.

Stetsko, T.I., Muzyka, V.P., \& Hunchak, V.M. (2018). Critically important antimicrobial preparations for veterinary medicine. Scientific Messenger of Lviv National University of Veterinary Medicine and Biotechnologies. 20(87), 19-26. doi: 10.15421/ nvlvet8704.

Papich, M.G., \& Riviere, J.E. (2001). Fluoroquinolone antimicrobial drugs. In: Adams HR, editor. Veterinary Pharmacology and Therapeutics, 8th ed. Ames: Iowa State University Press, 898-912.

Brown, S.A. (1996). Fluoroquinolones in animal health. J Vet Pharmacol Ther, 19(1), 1-14. doi: 10.1111/j.1365-2885.1996.tb00001.x.
Stetsko, T.I. (2005). Rezystentnist do ftorkhinoloniv: pokhodzhennia, evoliutsiia, klinichne znachennia ta shliakhy podolannia. Biolohiia tvaryn, 7(1-2), 51-63 (in Ukrainian).

Martinez-Martinez, L., Pascual, A., \& Jacoby, G.A. (1998). Quinolone resistance from a transferable plasmid. Lancet, 351(9105), 797-799. doi: 10.1016/S0140-6736(97)07322-4.

Metodychni vkazivky po vyznachenniu chutlyvosti mikroorhanizmiv do antymikrobnykh preparativ metodom dyfuzii v ahar za dopomohoiu standartnykh dyskiv $\mathrm{z}$ antybiotykamy (zatverdzheni Naukovometodychnoiu radoiu DKVM Ukrainy vid 20.12.2007 r.). Lviv, 2010 (in Ukrainian).

National Committee for Clinical Laboratory Standards (2004). Performance standards for antimicrobial disk and dilution susceptibility tests for bacteria isolated from animals; informational supplement. M31-S1. National Committee for Clinical Laboratory Standards, Wayne, PA.

Golovko, A.N., Ushkalov, V.A., \& Skrypnik, V.G. (2007). Mikrobiologicheskie i virusologicheskie issledovanija $\mathrm{v}$ veterinarnoj medicine. Spravochnoe posobie. Har'kov: NTMG (in Russian).

Kravtsiv, R.I., Zakhariv, O.Ia., Semeniuk, V.I., \& Turko, I.B. (2008). Veterynarna mikrobiolohiia. Posibnyk dlia vyshchykh navchalnykh zakladiv. Lviv, Lvivskyi natsionalnyi universytet veterynarnoi medytsyny ta biotekhnolohii imeni S.Z. Hzhytskoho (in Ukrainian).

Metodychni vkazivky po vyznachenniu bakteriostatychnoi ta bakterytsydnoi kontsentratsii antybakterialnykh preparativ metodom seriinykh rozveden (zatverdzheni naukovo-tekhnichnoiu radoiu DDVM Ukrainy Ministerstva ahropolityky Ukrainy vid 19.12.2002 r.). Kyiv, 2007 (in Ukrainian).

Fittipaldi, N, Segura, M, Grenier, D, \& Gottschalk, M. (2012). Virulence factors involved in the pathogenesis of the infection caused by the swine pathogen and zoonotic agent Streptococcus suis. Future Microbiol., 7(2), 259-279. doi: 10.2217/fmb.11.149.

Huang, Y.T., Teng, L.J., Ho, S.W., \& Hsueh, P.R. (2005). Streptococcus suis infection. J Microbiol Immunol Infect, 38(5), 306-313. https://www.ncbi.nlm.nih.gov /pubmed/16211137.

Gottschalk, M., Xu, J., Calzas, C., \& Segura, M. (2010). Streptococcus suis: a new emerging or an old neglected zoonotic pathogen? Future Microbiol, 5(3), 371-391. doi: 10.2217/fmb.10.2.

Orljankin, B.G., Aliper, T.I., Mishin, A.M. (2010). Infekcionnye respiratornye bolezni svinej: jetiologija, diagnostika i profilaktika. Veterinarija Kubani, 3. http://vetkuban.com/num3_20102.html (in Russian).

Zhao, Z., Wang, C., Xue, Y. et al. (2011). The occurrence of Bordetella bronchiseptica in pigs with clinical respiratory disease. Vet J., 188(3), 337-340. doi: $10.1016 /$ j.tvj1.2010.05.022. 